organizations to award fellowships and training grants in their special field and to permit other agencies to award fellowships within the recipient's own country. Travel grants totalling about 250 were made in 1958 to permit visits highly relevant to the recipient's plans and professional advancement; financial assistance was also given to key institutions, such as the Paulista School of Medicine in São Paulo, Brazil, which can assume roles of national and regional significance in developing leadership, as well as assist. ance to libraries, both in books and in the improvement of library techniques, and training within the Foundation's own operating programmes in agriculture and virus research. Among grants in 1958 in support of research highly relevant to development programmes, the President selects for mention those to Cornell University for research on crop yields, to Kyoto University for research on wheat, to the University of Alaska for studies of grasses and legumes, and to the National Research Council for research on foods rich in protein, while he emphasizes that the Foundation's most direct contribution to inter-cultural understanding takes the form of assistance to relevant university work in the humanitios and social seiences. He also stresses the Foundation's consistent policy of supporting pioneering work along the growing edges of knowledge and its general policy not to accept responsibility for physical plant. The Foundation also tends now to a policy of broad longer-term support of research projects, although it can do so in only a few selected cases, believing that this is a responsible adjustment to current changes and the need for stabilization and that it leaves decisions about specific research to those most closely concerned. Although in the period 1953-58 just under 65 per cent of the Foundation's expenditure or commitments of 637 million dollars was for institutions, organizations, scientists and scholars in the United States, these funds have often strengthened American institutions from which it has drawn its own staff and in which its Fellows might be trained for increased respons. ibility. Finally, it is noted that the Foundation continues to draw upon its capital funds to the extent of 5 million dollars a year to do more in Latin America, Africa, the Middle East and Asia than would be possible within its annual income, in view of the crucial importance of these present years for the peoples of these areas.

Dr. Weaver's brilliant survey, which occupies some 115 pages compared with the President's 25, is intended to gave a general account of the state of scientific advance in 1932 as a background to the explanation of the reasons which led the Foundation in 1933 to place major emphasis in its support of science on studies of living things. The bulk of the Report is a summary of the Foundation's subsequent activities under its Programme in Experimental Biology-a survey which covers advances in techniques and instruments as well as in our knowledge of the behaviour and structure of living things. Finally, glancing at the future, Dr. Weaver gives reasons for his belief that we are on the threshold of what should be a new era in biology.

\title{
INTERNATIONAL CONTROL OF NARCOTIC DRUGS
}

QINCE the first international conference on the $\checkmark$ control of narcotics, which met in 1909 in Shanghai, there has been universal recognition of the importance of preventing the abuse of narcotic drugs. Before the Second World War, the League of Nations undertook the necessary measures for international control of illicit traffic in opium, morphine and other drugs used by addicts. Through its Health Committee, the League also dealt with the medical problems involved in such control. When the League of Nations was dissolved its functions were conferred upon two international organizations: the policymaking and administrative functions were transferred to the United Nations Organization and the specifically medical aspects came within the purview of the World Health Organization.

The World Health Organization advises on the medical aspects of drug addiction and addictionproducing drugs. It is empowered to decide whether a newly discovered product is liable to produce addiction and should therefore be subject to international control. The Organization takes such decisions on the advice of an Expert Committee on the Addiction-Producing Drugs, the activities of which include the examination of drugs suspected of having addiction-producing properties. Since its inception, that is, during the past ten years, the Committee has examined 73 drugs and preparations, 55 of which were found to represent a danger to public health. The proceedings of the Committee, accompanied by statements on special problems raised by drug addiction, have been published in nine reports. It also advises on products which, although not addiction-producing drugs, can readily be converted into them. The same Committee has also given definitions of 'drug addiction' and 'drug habituation', taking into account pharmacological, psychological and public health aspects. These definitions have found world-wide acceptance. Recently, the range of drugs which need continual survey has been increased by the inclusion of hypnotic and tranquillizing, as well as stimulating, agents, although these do not lead to addiction in the strict sense of the definition.

The World Health Organization has also started to take an active interest in the treatment of drug addicts. In 1956 a Study Group on the Treatment and Care of Drug Addicts examined the medical features of drug addiction caused by opium, opiates, morphine-like synthetic drugs and cannabis, and outlined general principles as well as recommending rational methods of treatment and rehabilitation.

The chewing of coca leaves, which is so widespread in many parts of Latin America, and the increasing abuse of Cannabis are other important problems dealt with by the World Health Organization, which has decided that both habits represent a considerable danger to public health, and it has suggested the form which international control of these types of addiction should take.

The problem is complicated by the introduction of new therapeutic substances which may have addictionproducing properties and, above all, the continual discovery of new narcotics, mainly synthetic, which are submitted for international control every year. The World Health Organization follows developments very closely and, at the request of the Economic and 
Social Council, has undertaken studies on the chemical structure of synthetic substances with morphine-like effects, the relationship between their chemical structure and their analgesic action, and the relationship between the latter and their liability to produce addiction. The Organization has studied the thera- peutic properties and side effects-especially the addiction-producing properties-of 30 drugs of practical importance which have been put on the market as substitutes for morphine and codeine*.

* World Health Organization Chronicle, 13, No. 12 ; Necember 1959.

\section{MARRIAGE-RATE OF AMERICAN COLLEGE GRADUATES}

\begin{abstract}
COLLEGE graduates in the United States are now 1 marrying at a much earlier age than their parents. They are having children much sooner, having more children, spacing them much closer together, and seem to be following the general trend of the younger generation by completing their families earlier than their parents.

During 1946-1956, the College Study Group of the Population Reference Bureau, Inc., reported that the fertility of the younger college graduates was higher than that of the graduates of a generation ago (Population Bulletin, Vol. 15, No. 6: Fertility of College Graduates, Pp. 101-116 (Washington, D.C. : Population Reference Bureau, Inc., 1959.) 50 cents). Additional results, gathered in 1955 , have made it possible to measure the degree of these marriage and fertility differences in two college classes, those graduating in 1930 and in 1945. The average age at first marriage in 1955 in the United States was 23 for men and 20 for women. For the graduate class of 1945 , the average age at marriage was 24 years for both sexes and it was 25 years for both sexes for the class of 1930. Ten years after graduation, fewer of the younger graduates remained single: 13 per cent of the men and 10 per cent of the women among the younger graduates, compared with 20 per cent of the men and 27 per cent of the women among the older graduates.
\end{abstract}

The proportion not married ten years after graduation continued to be higher among graduates of Roman Catholic colleges : 20 per cent of the men and 23 per cent of the women in the class of 1945 , compared with 38 per cent of the men and 43 per cent of the women in the class of 1930 .

When the survey was taken in 1955 , the 10 -year women graduates of the class of 1945 who were about mid-way through their family-building years already had a greater average number of children than the 25 -year women of the class of 1930 , who had reached the end of the reproductive span. The men of both classes were parents of still more children than the women in both groups. Although the younger graduates had babies at a faster rate than the older graduates, their contribution to the post-war rise in the birth-rate was not as great as either high school or grade school graduates. The differential birthrate which has concerned eugenicists and others still persists. The 10-year women college graduates did not reach their fertility peak until 1952. Once they started having babies, they continued to have them over a longer period of time than other women of their age. These results confirm the belief that a great change in attitudes towards marriage and family has occurred in the United States, even among college graduates.

\section{PLANT POPULATION AND CROP YIELD \\ BY R. HOLLIDAY \\ Department of Agriculture, University of Leeds}

G RAPHICAL examination of the relation between crop yield and the number of plants per unit area suggests that two distinct types of curve may be obtained. One, typified by work by Engledow ${ }^{1}$ and Hudson ${ }^{2}$ on grain yield in wheat, is approximately parabolic in shape. With this type of curve a certain plant population gives a maximum yield, while greater or less populations give lower yields. Other workers have obtained similar curves in the case of seed, fruit or influorescence yield with other cereals, maize, sorghum, soya beans, peas, tomatoes, hops and both seed and lint yield in cotton.

Work at Leeds with wheat has given, in the case of straw yield, an increasing yield relation to a maximum but with no sign of yield decrease beyond this maximum up to populations established from 4 cwt. of seed per acre. This relation is referred to below as an asymptotic curve. In contrast, the yield of grain in most years showed a maximum at or about populations established from I cwt. of seed per acre. A similar contrast in dry matter yield plant population curves was obtained with pure sowings of perennial ryegrass ${ }^{3,4}$. In the seeding year, with yield resulting from vegetative growth, the curve was asymptotic up to populations established from $160 \mathrm{lb}$./acre; in the following year, where yield was a product of reproductive as well as vegetative growth, the curve showed a maximum at or about populations established from $20 \mathrm{Jb}$. of seed per acre. Donald ${ }^{5}$ in Australia obtained the same kind of contrast with Wimmera ryegrass and sub. terranean clover; the seed-yield curve showed a maximum, while the vegetative yield was asymptotic up to populations of $180 \times 10^{8}$ plants per acre in the case of ryegrass experiments.

Although the range of populations covered are sometimes rather limited, references in the literature would suggest that sugar beet, kale, mangolds, fodder beet, tea and timber yields, all of which are products of vegetative growth, show an asymptotic type of yield-plant population relation. 